\title{
Stem cells and other innovative intra-articular therapies for osteoarthritis: what does the future hold?
}

Jasvinder A Singh $1,2,3,4$

\begin{abstract}
Osteoarthritis (OA), the most common type of arthritis in the world, is associated with suffering due to pain, productivity loss, decreased mobility and quality of life. Systemic therapies available for OA are mostly symptom modifying and have potential gastrointestinal, renal, hepatic, and cardiac side effects. BMC Musculoskeletal Disorders recently published a study showing evidence of reparative effects demonstrated by homing of intra-articularly injected autologous bone marrow stem cells in damaged cartilage in an animal model of OA, along with clinical and radiographic benefit. This finding adds to the growing literature showing the potential benefit of intra-articular (IA) bone marrow stem cells. Other emerging potential IA therapies include IL-1 receptor antagonists, conditioned autologous serum, botulinum toxin, and bone morphogenetic protein-7. For each of these therapies, trial data in humans have been published, but more studies are needed to establish that they are safe and effective. Several additional promising new $\mathrm{OA}$ treatments are on the horizon, but challenges remain to finding safe and effective local and systemic therapies for OA.
\end{abstract}

Please see related article: http://www.biomedcentral.com/1471-2474/12/259

Keywords: osteoarthritis, intra-articular, novel, treatment, gene therapy, stem cell

\section{Background}

Osteoarthritis (OA) is the most common type of arthritis and the leading cause of disability in the United States [1]. OA alone is responsible for $\$ 3.4$ to $\$ 13.2$ billion in job-related costs every year in the US. [2,3] and is associated with significant healthcare utilization, deficits in quality of life, and productivity loss [4-7]. Several systemic treatments, mostly symptom-modifying rather than disease-modifying agents, are available for OA [8]. Recently published OA treatment guidelines highlight the strength of evidence for various therapies [9-12]. However, there is a real need for effective, safe, diseasemodifying $\mathrm{OA}$ therapies that can not only effectively treat those with established OA, but also possibly delay or prevent progression in those with early OA [13]. None of the potential therapies discussed in this

Correspondence: Jasvinder.md@gmail.com

${ }^{1}$ Medicine Service, Birmingham VA Medical Center and Department of Medicine, University of Alabama, Faculty Office Tower 805B, 510 20th Street S, Birmingham, AL 35294, USA

Full list of author information is available at the end of the article editorial have been approved by regulatory agencies such as the US Food and Drug Administration (FDA), and therefore these therapies are experimental.

\section{Stem cells for OA: a potential new treatment on the horizon?}

Stem cells can differentiate into different cell lineages due to their self-renewing and clonogenic capabilities [14]. Embryonic stem cells have the capability to differentiate into any terminally differentiated cell in the body [15]. Adult stem cells were originally believed to only differentiate into tissue-specific cells. However adult stem cells may be programmed under specific signals to differentiate into other organ-specific cells with a phenotype distinct from that of the precursor. Certain barriers that exist to achieving this effectively in vivo must be overcome, namely, easy accessibility to sufficient concentration of stem cells at the site of tissue repair and generation of appropriate signals from the tissue repair site directing the cells to the site [15]. Stem cells can be administered via systemic intravascular route or a direct local implantation, such as that 
done to repair infracted myocardium $[16,17]$ and in spinal cord injuries [18]. In a recent study by Mokbel et al. in BMC Musculoskeletal Disorders, labeled autologous adult stem cells suspended in hyaluronic acid were injected intra-articularly into carpal joints in an experimental arthritis induced by intra-articular (IA) Amphotericin-B in donkeys [19]. Significant improvement was noted in clinical and radiographic OA and significantly lesser histopathological changes of OA were seen in carpal joints that received IA autologous mesenchymal stem cells compared to control contralateral joints that received IA hyaluronic acid [19]. Importantly, injected stem cells were incorporated into the articular cartilage of the injected joint, as evident by their integration in the surface of the cartilage and also the interior of the cartilage. Interestingly, while some of these cells showed a chondrocyte-like phenotype indicating their differentiation, other injected cells retained spindle-like structure, characteristic of the mesenchymal origin. Previous studies have suggested that bone marrow and synovial mesenchymal stem cells have more chondrogenic potential compared to adipose or muscle mesenchymal stem cells [20]. While other studies have provided evidence that stem cells may offer potential therapeutic benefit in OA $[21,22]$, challenges remain in the translation of this knowledge into available therapies for patients with OA. The challenges include homing of adequate number of cells in the tissues undergoing repair, long-term safety of such approaches especially those using viral vectors, the durability of the benefit, and feasibility of providing these treatments in busy practitioners' offices. Despite the challenges in bringing this potential therapy to clinic, stem cell therapy offers a revolutionary approach to the treatment of OA.

\section{New pharmacotherapies for intra-articular use in osteoarthritis}

While stem cell therapy may constitute a potential therapy for OA patients in the future, there is need for additional new effective and safe treatment options. Currently available systemic treatments for OA symptoms are commonly associated with gastrointestinal, hepatic, renal, and/or cardiac adverse events, especially in the elderly [8]. This makes IA and local therapies attractive options, especially for patients with limited OA in the knee or hip joints. The counter-argument is that $\mathrm{OA}$ is a systemic disease in many patients with involvement of several joints, and therefore there is also a great need for new systemic therapies. Additionally, IA administration may provide a higher concentration of the medication in the joint macro and micro environment, including the cartilage and synovium, and avoid several systemic adverse events [23]. The disadvantage of rare infection following IA injection $(0.002 \%)$ [24] is far outweighed by its advantages. We discuss a few interesting potential new IA therapies with evidence of early efficacy in human OA. A more complete list is provided in Table 1.

Interluekin-1 beta (IL-1 $\beta$ ), thought to play an important role in OA pathology, was targeted with IL-1 receptor antagonist administered IA (at 2 doses, $50 \mathrm{mg}$ and $150 \mathrm{mg}$ ) as a single injection in 170 patients [25] and an antibody against IL-1 administered subcutaneously every 4 weeks for three months in 149 patients [26] in one placebo-controlled randomized controlled trial (RCT) each. There were no significant differences in the primary outcome, the Western Ontario McMaster Arthritis Index (WOMAC) scores, at 4-6 weeks follow-up between treatment and placebo groups, in either study. Biochemical and histopathogical changes, including decrease in synovial inflammation and hypertrophy, reduction in highly sensitive C-reactive protein and increase in proteoglycan content, were noted in the patients who received the active treatment. A high placebo response and short halflife of the molecule in the joint may be partially responsible for lack of an effect. It remains to be seen whether modifying the available preparations of IL- $1 \beta$ and/or targeting other cytokine targets in addition to IL-1 $\beta$, can provide an effective treatment option.

There has been significant recent interest in the use of autologous conditioned serum, which is derived by incubating patient's serum with glass beads to induce the release of several anti-inflammatory cytokines such as IL-1 receptor antagonist, IL-4, IL-10, and IL-13, centrifuged and injected intra-articularly into the joints. However, the early results from two RCTs in humans are contradictory. One RCT of six IA injections showed no significant difference in WOMAC scores (primary outcome) compared to IA saline [27], while the other RCT reported significantly better outcome in IA autologous conditioned serum group, compared to IA hyaluronic acid or IA saline [28].

Another interesting approach is the use of IA botulinum toxin, which is hypothesized to have antinociceptive and possibly anti-inflammatory action. In three RCTs of a single IA injection of botulinum toxin in to 43-60 painful joints each (with painful OA or painful arthroplasty with OA as the underlying condition), clinically and statistically significant improvements in primary outcome of pain as well as extremity function (on WOMAC and shoulder indices) were noted in IA botulinum toxin group (with or without lidocaine) compared to control treatment (saline or saline plus lidocaine) [29-31]. In another RCT, IA botulinum toxin had efficacy similar to IA corticosteroid [32]. Botulinum toxin is known to inhibit substance $\mathrm{P}$ and calcitonin-gene related protein [33-36], the main mediators of neurogenic inflammation, a phenomenon of vasodilatation, protein extravasation, and stimulation of inflammatory cells induced by antidromic stimulation of primary afferent fiber [37]. 
Table 1 Emerging intra-articular therapies for osteoarthritis

\begin{tabular}{|c|c|}
\hline Therapy/Drug development stage & Proposed mechanism of action \\
\hline \multicolumn{2}{|l|}{ Evidence from Human Studies } \\
\hline $\begin{array}{l}\text { Interleukin-1 (IL-1) inhibitor }[25,26,44] \\
2 \text { Phase II/III trials }\end{array}$ & Inhibition of IL-1, a pro-inflammatory cytokine that promotes cartilage degradation \\
\hline $\begin{array}{l}\text { Human autologous conditioned serum }[27,28] \\
2 \text { Phase II/III trials }\end{array}$ & Production of anti-inflammatory cytokines such as IL-1 receptor antagonist, IL-4, IL-10, and IL-13 \\
\hline $\begin{array}{l}\text { Botulinum toxin [29-32] } \\
3 \text { Phase II/III trials }\end{array}$ & $\begin{array}{l}\text { Inhibition of release of release of Substance } \mathrm{P} \text {, calcitonin gene-related protein and glutamate from } \\
\text { primary afferent neuron terminals }\end{array}$ \\
\hline $\begin{array}{l}\text { Recombinant human bone morphogenetic } \\
\text { protein-7 (BMP-7) }[38,45] \\
1 \text { Phase I trial }\end{array}$ & $\begin{array}{l}\text { Stimulation of proteoglycan, collagen and hyaluronic acid synthesis; induction of receptors, } \\
\text { prevention of catabolism of cartilage components by interleukin (IL)-1 }\end{array}$ \\
\hline $\begin{array}{l}\text { Human platelet rich plasma (PRP) }[39,40] \\
\text { Case series }(n=14)\end{array}$ & Stimulation of chondrogenesis, increase in hyaluronic acid production, stabilization of angiogenesis \\
\hline \multicolumn{2}{|l|}{ Evidence from Animal Models } \\
\hline Fibroblast growth factor-18 (FGF-18) $[41,42,46]$ & Stimulation or stabilization of bio-synthesis of cartilage matrix components \\
\hline Platelet-derived growth factor (PDGF) [43] & $\begin{array}{l}\text { Increase in cell proliferation and proteoglycan production; stimulation of meniscal cell proliferation } \\
\text { and migration }\end{array}$ \\
\hline Insulin-like growth factor (IGF) $[42,43,47]$ & $\begin{array}{l}\text { Improvement in cartilage homeostasis by balancing proteoglycan synthesis and breakdown; } \\
\text { reduction in synovial inflammation }\end{array}$ \\
\hline Caspase inhibitors $[48,49]$ & Inhibition of chondrocyte death apoptosis \\
\hline Human Kallistatin [50] & Suppression of inflammatory responses and reduce cell apoptosis \\
\hline Interleukin-6 (IL-6) inhibitor [51] & $\begin{array}{l}\text { Inhibition of hypoxia-inducible factor } 2 \text { alpha-induced cartilage destruction by regulating matrix } \\
\text { metalloproteinase } 3 \text { (MMP3) and MMP13 }\end{array}$ \\
\hline Recombinant human PRG4 (rhPRG4) [52] & Replacement of lubricin, that has lubricant and anti-adhesive properties and is chondroprotective \\
\hline Recombinant human OPG (rHuOPG) [53] & Suppression of chondrocyte apoptosis \\
\hline Leptin [54] & $\begin{array}{l}\text { Stimulation of synthesis of IGF-1 and TGF beta1 to stimulate chondrocytes to repair extracellular } \\
\text { matrix }\end{array}$ \\
\hline Mu-opioid receptor [55] & $\begin{array}{l}\text { Reduction of substance } P \text { and neurotransmitter release from sensory nerve endings peripherally and } \\
\text { centrally }\end{array}$ \\
\hline Dehydroepiandrosterone [56] & $\begin{array}{l}\text { Modulate the imbalance between matrix metalloproteinases (MMPs) and tissue inhibitor of } \\
\text { metalloproteinases } 1 \text { (TIMP-1) }\end{array}$ \\
\hline $\begin{array}{l}\text { Berberine, a traditional Chinese medication } \\
\text { [57] }\end{array}$ & Reduction of MMP-3 and MMP-13 levels \\
\hline \multicolumn{2}{|l|}{ Evidence from in vitro studies } \\
\hline Fibroblast growth factor-2 (FGF-2) [58] & Stimulation of chondrocyte progenitor cells \\
\hline N-acetylcysteine [59] & Increase in chondrocyte viability by reducing oxidative damage \\
\hline
\end{tabular}

Another therapy on the horizon targets bone morphogenetic protein-7 (BMP-7). In a phase I tolerability and safety study, IA recombinant human BMP-7 showed a higher response rate in treatment compared to the placebo group [38]. Other innovative therapies including human platelet-rich plasma $[39,40]$, fibroblast growth factor-18 (FGF-18) [41,42], platelet-derived growth factor (PDGF) [43], and insulin-like growth factor (IGF) [43] are being tested in early (animal and early human) studies for their potential to repair cartilage (Table 1).

\section{Conclusions: we are not there yet, but we are on our way}

The interesting study by Mokbel et al. [18] provides additional evidence from animal models for the potential of autologous mesenchymal bone marrow stem cells as a potential future treatment for OA. Early evidence from human RCTs is also available for additional IA therapies such as IL-1 $\beta$ antagonists, autologous conditioned serum and botulinum toxin. Whether these approaches will translate into effective and safe therapies for humans remains to be seen. This next step will need more convincing evidence of therapeutic efficacy and safety in humans in large RCTs and correlation with improvements in disease pathophysiology, with the use of serum and joint biomarkers and/or imaging biomarkers (radiographs, magnetic resonance imaging, and so on). The future of OA therapeutics seems bright, with a lot of potential therapies targeting different mechanisms of action, different pathways and different approaches for this disabling disease.

\footnotetext{
Acknowledgements

I thank Dr David Hunter for helpful suggestions related to this manuscript. No specific grant was obtained to support this work. This material is the result of work supported by the resources and the use of facilities at the Birmingham VA Medical Center, Alabama, USA. JAS is also supported by
} 
research grants from the National Institute of Aging, National Cancer Institute, and Agency for Health Quality and Research Center for Education and Research on Therapeutics (CERTs).

The views expressed in this article are those of the authors and do not necessarily reflect the position or policy of the Department of Veterans Affairs or the United States government.

\section{Author details}

Medicine Service, Birmingham VA Medical Center and Department of Medicine, University of Alabama, Faculty Office Tower 805B, 510 20th Street S, Birmingham, AL 35294, USA. ${ }^{2}$ Center for Surgical Medical Acute care Research and Transitions (C-SMART), Birmingham VA Medical Center, Birmingham, AL, USA. 'Division of Epidemiology, School of Public Health, University of Alabama, Birmingham, AL, USA. ${ }^{4}$ Department of Orthopedic Surgery, Mayo Clinic School of Medicine, Rochester, MN, USA.

\section{Authors' contributions}

JAS: Concept of the editorial, literature review, preparation of editorial, and revision of the manuscript.

\section{Authors' information}

JAS is a rheumatologist-epidemiologist, an Associate Professor of Medicine and Epidemiology at the University of Alabama at Birmingham and staff physician at the Birmingham Veterans Affairs Medical Center. JAS is a member of the American College of Rheumatology and serves as a committee member on the Guidelines subcommittee of the American College of Rheumatology's Quality of Care committee, Veterans Affairs Rheumatology Field Advisory Committee, and the executive committee of the Outcome Measures in Rheumatology Trials (OMERACT).

\section{Competing interests}

There are no financial conflicts related to this work. JAS has received investigator-initiated research and travel grants from Takeda, Allergan and Savient; consultant fees from Takeda, Ardea, Savient, Allergan, Novartis, and URL pharmaceuticals; and is a member of the executive of OMERACT, an organization that develops outcome measures in rheumatology and receives arms-length funding from 36 companies.

Received: 24 April 2012 Accepted: 2 May 2012 Published: 2 May 2012

\section{References}

1. Centers for Disease Control and Prevention: Prevalence and Most Common Causes of Disability Among Adults - United States, 2005. MMWR Morb Mortal Wkly Rep 2009, 58:421-426.

2. Centers for Disease Control and Prevention, Arthritis Foundation: $\mathrm{A}$ National Public Health Agenda for Osteoarthritis. 2010 [http://www.cdc. gov/arthritis/docs/OAagenda.pdf]

3. Buckwalter JA, Saltzman C, Brown T: The impact of osteoarthritis: implications for research. Clin Orthop Relat Res 2004, , 427 Suppl: S6-15.

4. Michon M, Maheu E, Berenbaum F: Assessing health-related quality of life in hand osteoarthritis: a literature review. Ann Rheum Dis 2011, 70:921-928.

5. Oiestad BE, Holm I, Engebretsen L, Risberg MA: The association between radiographic knee osteoarthritis and knee symptoms, function and quality of life 10-15 years after anterior cruciate ligament reconstruction. Br J Sports Med 2011, 45:583-588.

6. Lopez AD, Murray CC: The global burden of disease, 1990-2020. Nat Med 1998, 4:1241-1243.

7. Zhang Y, Niu J, Kelly-Hayes M, Chaisson CE, Aliabadi P, Felson DT: Prevalence of symptomatic hand osteoarthritis and its impact on functional status among the elderly: The Framingham Study. Am J Epidemiol 2002, 156:1021-1027.

8. Sinusas K: Osteoarthritis: diagnosis and treatment. Am Fam Physician 2012, 85:49-56.

9. Hochberg M, Altman R, April KP, Benkhalti M, Guyatt G, McGowan J, Townheed T, Welch V, Wells G, Tugwell P: American College of Rheumatology 2012 Recommendations for the Use of Nonpharmacologic and Pharmacologic Therapies in Osteoarthritis of the Hand, Hip, and Knee. Arthritis Care \& Research 2012, 64:465-474.

10. Zhang W, Moskowitz RW, Nuki G, Abramson S, Altman RD, Arden N, Bierma-Zeinstra S, Brandt KD, Croft P, Doherty M, Dougados M,
Hochberg M, Hunter DJ, Kwoh K, Lohmander LS, Tugwell P: OARSI recommendations for the management of hip and knee osteoarthritis, Part II: OARSI evidence-based, expert consensus guidelines. Osteoarthritis Cartilage 2008, 16:137-162.

11. Zhang W, Doherty M, Leeb BF, Alekseeva L, Arden NK, Bijlsma JW, Dincer F, Dziedzic K, Hauselmann HJ, Kaklamanis P, Kloppenburg M, Lohmander LS, Maheu E, Martin-Mola E, Pavelka K, Punzi L, Reiter S, Smolen J, Verbruggen G, Watt I, Zimmermann-Gorska I, ESCISIT: EULAR evidencebased recommendations for the diagnosis of hand osteoarthritis: report of a task force of ESCISIT. Ann Rheum Dis 2009, 68:8-17.

12. Zhang W, Moskowitz RW, Nuki G, Abramson S, Altman RD, Arden N, Bierma-Zeinstra S, Brandt KD, Croft P, Doherty M, Dougados M Hochberg M, Hunter DJ, Kwoh K, Lohmander LS, Tugwell P: OARSI recommendations for the management of hip and knee osteoarthritis, part I: critical appraisal of existing treatment guidelines and systematic review of current research evidence. Osteoarthritis Cartilage 2007, 15:981-1000

13. Hunter DJ: Osteoarthritis. Best Pract Res Clin Rheumatol 2011, 25:801-814.

14. Weissman IL: Stem cells: units of development, units of regeneration, and units in evolution. Cell 2000, 100:157-168.

15. Korbling $M$, Estrov Z: Adult stem cells for tissue repair - a new therapeutic concept? N Engl J Med 2003, 349:570-582.

16. Jiang W, Ma A, Wang T, Han K, Liu Y, Zhang Y, Dong A, Du Y, Huang X Wang J, Lei $X$, Zheng $X$ : Homing and differentiation of mesenchymal stem cells delivered intravenously to ischemic myocardium in vivo: a time-series study. Pflugers Arch 2006, 453:43-52.

17. Kollar K, Cook MM, Atkinson K, Brooke G: Molecular mechanisms involved in mesenchymal stem cell migration to the site of acute myocardial infarction. Int J Cell Biol 2009, 2009:904682.

18. Hu SL, Luo HS, Li JT, Xia YZ, Li L, Zhang LJ, Meng H, Cui GY, Chen Z, Wu N, Lin JK, Zhu G, Feng $H$ : Functional recovery in acute traumatic spinal cord injury after transplantation of human umbilical cord mesenchymal stem cells. Crit Care Med 2010, 38:2181-2189.

19. Mokbel AN, El Tookhy OS, Shamaa AA, Rashed LA, Sabry D, El Sayed AM: Homing and reparative effect of intra-articular injection of autologus mesenchymal stem cells in osteoarthritic animal model. BMC Musculoskelet Disord 2011, 12:259.

20. Koga H, Shimaya M, Muneta T, Nimura A, Morito T, Hayashi M, Suzuki S, Ju YJ, Mochizuki T, Sekiya I: Local adherent technique for transplanting mesenchymal stem cells as a potential treatment of cartilage defect. Arthritis Res Ther 2008, 10:R84.

21. Noth U, Steinert AF, Tuan RS: Technology insight: adult mesenchymal stem cells for osteoarthritis therapy. Nat Clin Pract Rheumatol 2008, 4:371-380

22. Murphy JM, Fink DJ, Hunziker EB, Barry FP: Stem cell therapy in a caprine model of osteoarthritis. Arthritis Rheum 2003, 48:3464-3474.

23. Chevalier $X$ : Intraarticular treatments for osteoarthritis: new perspectives. Curr Drug Targets 2010, 11:546-560.

24. Bellamy N, Campbell J, Robinson V, Gee T, Bourne R, Wells G: Intraarticular corticosteroid for treatment of osteoarthritis of the knee. Cochrane Database Syst Rev 2006, , 2: CD005328.

25. Chevalier X, Goupille P, Beaulieu AD, Burch FX, Bensen WG, Conrozier T, Loeuille D, Kivitz AJ, Silver D, Appleton BE: Intraarticular injection of anakinra in osteoarthritis of the knee: a multicenter, randomized, double-blind, placebo-controlled study. Arthritis Rheum 2009, 61:344-352.

26. Cohen S, Proudman S, Kivitz Aea: Results of a randomised controlled trial of AMG 108 (a fully monoclonal human antibody to ILR type 1) in patients with osteoarthritis of the knee. Arthritis Rheum 2007, , Suppl 9: 1684.

27. Yang KG, Raijmakers NJ, van Arkel ER, Caron JJ, Rijk PC, Willems WJ, Zijl JA Verbout AJ, Dhert WJ, Saris DB: Autologous interleukin-1 receptor antagonist improves function and symptoms in osteoarthritis when compared to placebo in a prospective randomized controlled trial. Osteoarthritis Cartilage 2008, 16:498-505.

28. Baltzer AW, Moser C, Jansen SA, Krauspe R: Autologous conditioned serum (Orthokine) is an effective treatment for knee osteoarthritis. Osteoarthritis Cartilage 2009, 17:152-160.

29. Singh JA, Mahowald ML, Noorbaloochi S: Intraarticular botulinum toxin A for refractory painful total knee arthroplasty: a randomized controlled trial. J Rheumatol 2010, 37:2377-2386. 
30. Singh JA, Mahowald ML, Noorbaloochi S: Intra-articular botulinum toxin A for refractory shoulder pain: a randomized, double-blinded, placebocontrolled trial. Transl Res 2009, 153:205-216.

31. Mahowald ML, Singh JA, Dykstra D: Long term effects of intra-articular botulinum toxin A for refractory joint pain. Neurotox Res 2006, 9:179-188.

32. Boon AJ, Smith J, Dahm DL, Sorenson EJ, Larson DR, Fitz-Gibbon PD, Dykstra DD, Singh JA: Efficacy of intra-articular botulinum toxin type A in painful knee osteoarthritis: a pilot study. PM R 2010, 2:268-276.

33. Meng J, Wang J, Lawrence G, Dolly JO: Synaptobrevin I mediates exocytosis of CGRP from sensory neurons and inhibition by botulinum toxins reflects their anti-nociceptive potential. J Cell Sci 2007, 120:2864-2874

34. Purkiss J, Welch M, Doward S, Foster K: Capsicin Stimulated Release of Substance P from Cultured Dorsal Root Ganglion Neurons: Involvement of Two Distinct Mechanisms. Biochem Pharmacol 2000, 59:1403-1406

35. Lucioni A, Bales GT, Lotan TL, McGehee DS, Cook SP, Rapp DE: Botulinum toxin type $A$ inhibits sensory neuropeptide release in rat bladder models of acute injury and chronic inflammation. BJU Int 2008, 101:366-370

36. Rapp DE, Turk KW, Bales GT, Cook SP: Botulinum toxin type a inhibits calcitonin gene-related peptide release from isolated rat bladder. J Urol 2006, 175:1138-1142

37. Birklein F, Schmelz M: Neuropeptides, neurogenic inflammation and complex regional pain syndrome (CRPS). Neurosci Lett 2008, 437:199-202.

38. Hunter DJ, Pike MC, Jonas BL, Kissin E, Krop J, McAlindon T: Phase 1 safety and tolerability study of BMP-7 in symptomatic knee osteoarthritis. BMC Musculoskelet Disord 2010, 11:232

39. Sampson $S$, Reed M, Silvers $H$, Meng M, Mandelbaum B: Injection of platelet-rich plasma in patients with primary and secondary knee osteoarthritis: a pilot study. Am J Phys Med Rehabil 2010, 89:961-969.

40. Kruger JP, Hondke S, Endres M, Pruss A, Siclari A, Kaps C: Human plateletrich plasma stimulates migration and chondrogenic differentiation of human subchondral progenitor cells. J Orthop Res 2012, 30:845-852.

41. Moore EE, Bendele AM, Thompson DL, Littau A, Waggie KS, Reardon B, Ellsworth JL: Fibroblast growth factor-18 stimulates chondrogenesis and cartilage repair in a rat model of injury-induced osteoarthritis. Osteoarthritis Cartilage 2005, 13:623-631.

42. Chen B, Qin J, Wang H, Magdalou J, Chen L: Effects of adenovirusmediated bFGF, IL-1Ra and IGF-1 gene transfer on human osteoarthritic chondrocytes and osteoarthritis in rabbits. Exp Mol Med 2010, 42:684-695.

43. Schmidt MB, Chen EH, Lynch SE: A review of the effects of insulin-like growth factor and platelet derived growth factor on in vivo cartilage healing and repair. Osteoarthritis Cartilage 2006, 14:403-412.

44. Pelletier JP, Caron JP, Evans C, Robbins PD, Georgescu HI, Jovanovic D, Fernandes JC, Martel-Pelletier J: In vivo suppression of early experimental osteoarthritis by interleukin-1 receptor antagonist using gene therapy. Arthritis Rheum 1997, 40:1012-1019.

45. Honsawek S, Chayanupatkul M, Tanavalee A, Sakdinakiattikoon M, Deepaisarnsakul B, Yuktanandana P, Ngarmukos S: Relationship of plasma and synovial fluid BMP-7 with disease severity in knee osteoarthritis patients: a pilot study. Int Orthop 2009, 33:1171-1175.

46. Ellsworth JL, Berry J, Bukowski T, Claus J, Feldhaus A, Holderman S, Holdren MS, Lum KD, Moore EE, Raymond F, Ren H, Shea P, Sprecher C, Storey H, Thompson DL, Waggie K, Yao L, Fernandes RJ, Eyre DR, Hughes SD: Fibroblast growth factor-18 is a trophic factor for mature chondrocytes and their progenitors. Osteoarthritis Cartilage 2002. 10:308-320.

47. Fortier LA, Mohammed HO, Lust G, Nixon AJ: Insulin-like growth factor-I enhances cell-based repair of articular cartilage. J Bone Joint Surg Br 2002, 84:276-288.

48. D'Lima D, Hermida J, Hashimoto S, Colwell C, Lotz M: Caspase inhibitors reduce severity of cartilage lesions in experimental osteoarthritis. Arthritis Rheum 2006, 54:1814-1821.

49. Huser CA, Peacock M, Davies ME: Inhibition of caspase-9 reduces chondrocyte apoptosis and proteoglycan loss following mechanical trauma. Osteoarthritis Cartilage 2006, 14:1002-1010

50. Hsieh JL, Shen PC, Shiau AL, Jou IM, Lee CH, Teo ML, Wang CR, Chao J, Chao L, Wu CL: Adenovirus-mediated kallistatin gene transfer ameliorates disease progression in a rat model of osteoarthritis induced by anterior cruciate ligament transection. Hum Gene Ther 2009, 20:147-158.
51. Ryu JH, Yang S, Shin Y, Rhee J, Chun CH, Chun JS: Interleukin-6 plays an essential role in hypoxia-inducible factor 2alpha-induced experimental osteoarthritic cartilage destruction in mice. Arthritis Rheum 2011, 63:2732-2743.

52. Jay GD, Fleming BC, Watkins BA, McHugh KA, Anderson SC, Zhang LX Teeple E, Waller KA, Elsaid KA: Prevention of cartilage degeneration and restoration of chondroprotection by lubricin tribosupplementation in the rat following anterior cruciate ligament transection. Arthritis Rheum 2010, 62:2382-2391.

53. Shimizu S, Asou Y, Itoh S, Chung UI, Kawaguchi H, Shinomiya K, Muneta T: Prevention of cartilage destruction with intraarticular osteoclastogenesis inhibitory factor/osteoprotegerin in a murine model of osteoarthritis. Arthritis Rheum 2007, 56:3358-3365.

54. Dumond H, Presle N, Terlain B, Mainard D, Loeuille D, Netter P, Pottie P: Evidence for a key role of leptin in osteoarthritis. Arthritis Rheum 2003, 48:3118-3129.

55. Kyrkanides S, Fiorentino PM, Miller JN, Gan Y, Lai YC, Shaftel SS, Puzas JE, Piancino MG, O'Banion MK, Tallents RH: Amelioration of pain and histopathologic joint abnormalities in the Col1-IL-1beta(XAT) mouse model of arthritis by intraarticular induction of mu-opioid receptor into the temporomandibular joint. Arthritis Rheum 2007, 56:2038-2048.

56. Jo H, Ahn HJ, Kim EM, Kim HJ, Seong SC, Lee I, Lee MC: Effects of dehydroepiandrosterone on articular cartilage during the development of osteoarthritis. Arthritis Rheum 2004, 50:2531-2538.

57. Hu PF, Chen WP, Tang JL, Bao JP, Wu LD: Protective effects of berberine in an experimental rat osteoarthritis model. Phytother Res 2011, 25:878-885.

58. Henson FM, Bowe EA, Davies ME: Promotion of the intrinsic damagerepair response in articular cartilage by fibroblastic growth factor-2. Osteoarthritis Cartilage 2005, 13:537-544.

59. Martin JA, McCabe D, Walter M, Buckwalter JA, McKinley TO: Nacetylcysteine inhibits post-impact chondrocyte death in osteochondral explants. J Bone Joint Surg Am 2009, 91:1890-1897.

\section{Pre-publication history}

The pre-publication history for this paper can be accessed here: http://www.biomedcentral.com/1741-7015/10/44/prepub

doi:10.1186/1741-7015-10-44

Cite this article as: Singh: Stem cells and other innovative intra-articular therapies for osteoarthritis: what does the future hold? BMC Medicine 2012 10:44.

\section{Submit your next manuscript to BioMed Central and take full advantage of:}

- Convenient online submission

- Thorough peer review

- No space constraints or color figure charges

- Immediate publication on acceptance

- Inclusion in PubMed, CAS, Scopus and Google Scholar

- Research which is freely available for redistribution

Submit your manuscript at www.biomedcentral.com/submit
C Biomed Central 